\title{
Decolonising and Displaying Ancient Palestine: Baron Plato von Ustinow's Collection of Antiquities
}

\author{
Ruth Kark, Astri K. Lundgren \& Laszlo Berczelly
}

\begin{abstract}
This paper examines how Plato von Ustinow (1833-1920/21)*, a Russian aristocrat and German baron, became one of the nineteenth century's most prolific collectors of antiquities from Israel, Palestine and the surrounding areas. It investigates how Ustinow collected archaeological artefacts and displayed them in an 'exhibition hall' located at his bome Hôtel du Parc, in Jaffa (Tel Aviv), from 1878 to 1913. Until recently, Ustinow's private museum has been interpreted in the light of cultural revitalisation, as well as a sentimental attempt to inspire research and provide educational resources. However, postcolonial studies demonstrate that during the nineteenth-and early twentieth centuries, scholars from Europe and the USA sought 'proof' of past civilisations. Today, collections that were constructed from this kind of cultural material are considered problematic. Many heritage sites and items of global importance were destroyed, disturbed, pillaged, traded and included in public and private collections without contextual information. The present text takes a deep dive into the history and formation of the Ustinow collection, now in the Museum of Cultural Heritage in Oslo, seeking to recover (to the extent possible) the wealth of empirical evidence which can further elucidate archaeological material from the Near East.
\end{abstract}

Keywords: archaeology of ancient Palestine, Plato von Ustinow, collection of antiquities, Museum of Cultural History at Oslo

This paper offers a decolonisation approach to the formation of Plato Ustinow's collection and exhibition of material culture from ancient Israel, Palestine and surrounding areas. Building on Ustinow's personal life, it explores the socio-political circumstances in the Middle East and the archaeological traditions of the nineteenth- and early twentieth centuries. ${ }^{1}$ Through this perspective, the focus shifts from an oversimplified protectionist understanding of Ustinow's collection of antiquities as a visualisation of

\footnotetext{
* Please note that this article follows the Germanized form Ustinow from the Russian Oustinoff/Ustinoff when addressing Baron Plato Von Ustinow throughout the text while other family members are alluded to by the English version Ustinov. See Perry \& Yodim 2003, 150; Smidt 2005, 29-47.
} 
international patrimony towards addressing practices involving issues of entitlement to heritage objects. In this way, rather than concentrating on collecting and exhibiting antiquities, which suggests that private collectors of ancient artefacts were attracted to the material past based on 'universal' and identical motives, the adopted framework highlights the symbiotic relationship between society and material culture. To some critics, such an approach may seem vague and speculative, but it has been deliberately selected to connect the rationale behind Ustinow's collection with social constructions of archaeological knowledge. Moreover, by drawing on anthropologist Lynn Meskell's concept of 'rooted cosmopolitanism', the intangible interests involving colonialist attitudes to cultural heritage versus respect for heritage practices are re-evaluated. ${ }^{2}$ In archaeology and preservation ethics, the term applies to conflicting policies on cultural differences where nationalism alongside colonialism may undervalue how artefacts safeguard ancient authenticity and cultural identity, but also function as social agents. In our case, the spatial vicinity central to rooted cosmopolitanism is of particular interest, since such a framework offers useful tools for defining Western understanding of heritage values, archaeological sites and objects. It will be argued that the Middle East and its heritage landscape were regarded by the West as little more than a distant and underdeveloped province of the Ottoman Empire. Widely known as the origin of Jaffa oranges, the region also lacked modern industry and economic stability according to Western standards of productivity. ${ }^{3}$

Before the signing of the UNESCO Convention on the Means of Probibiting and Preventing the Illicit Import, Export and Transfer of Ownership of Cultural Property in 1970 and 1972, the antiquities trade was supported by profit-driven dealers who acquired items by theft, clandestine excavation and illicit transport. ${ }^{4}$ The Western position on cultural heritage saw artefacts and heritage landscapes from an essentialist perspective. Therefore, many items which were unearthed were treated as 'passive' material culture and sold to foreign collectors (who bought objects without recorded histories). Some were purchased via the art market and ended up in private collections and museum galleries abroad. As a result, the agency of Palestine and its remote past was dominated by colonial nation-states who used archaeology to celebrate the glorious and enduring past of Western civilisation, reaffirming the roles of European aristocrats as active stakeholders and protectors of universal cultural heritage. ${ }^{5}$

One might expect that the issues described above would merit special attention in previous works. Much scholarship has been produced on

\footnotetext{
2 For discussions on 'rooted cosmopolitanism', see Cohen 1992, 480; González-Ruibal 2009, 114; Meskell \& Van Damme 2007, 132-134; Meskell 2009, 3-4; 2015, 479-490.

3 Weissbrod 1992, 14; Sicker 1999, 4-7; Masalha 2007, 47.

${ }^{4}$ Stanley-Price 2001, 269; Walsh 2010, 251; Mackenzie 2011, 69-85.

5 Trigger 1989, 35-36; Ciulisová 2006, 202-203; Elina 2018, 261.
} 
the history of collecting. However, developments in archaeology, civil law and the relationship between the Westernisation of the Middle East are frequently downplayed, as are the long-term effects of private collecting. In studies on the antiquities trade, dealers and collectors, archaeologist Ricardo J. Elia notes that the "basic assumptions seem to be that looters are bad but collectors are good. Scholars who work with looted material regularly condemn looting, while in the same breath they laud the enthusiasm of the collector who, directly or indirectly, financed the looting' ${ }^{6}$ In this context, we examine the nexus between symbolic heritage, commodification and the importance of archaeological objects in shaping cultural differences.

\section{Plato Grigorievich Ustinow and the emergence of archaeological science}

It is helpful to approach the discussion by first considering how other researchers have viewed Plato Grigorievich Ustinow and his motivations for collecting and displaying material culture from Palestine (Fig. 1). In the course of almost fifty years as a private collector of cultural objects, Ustinow amassed approximately 3,000-4,000 artefacts. The core of his collection included seals, manuscripts, architectural fragments, signets, coins, vessels and funerary epitaphs, as well as fragmentary mammoth bones, several sarcophagi and Latin and Greek inscriptions.

The fourth child and second son of a wealthy Saratovan merchant, Grigori Mikhailovich Ustinow (1803-1860), and noblewoman, Maria Ivanovna Panshina, young Plato Ustinow was educated according to conservative aristocratic standards at the military academy in Saint Petersburg. During his years at the academy, Ustinow was introduced to history, classical works, natural law and ancient philosophy. After suffering a serious injury during a military drill while serving as an officer in the cavalry regiment of the Russian army, the young Ustinow dedicated himself to further studies in classical literature, archaeology and theology during his years of slow recovery. In 1875 he converted from Russian Orthodoxy to Protestantism. Under Russian law, only Orthodox subjects loyal to Tsar Alexander II and the motherland were permitted to own land. By refusing to take the 'Oath of the Little father of all the Russias' (the declaration of allegiance sworn by all Russian nobles), Ustinow also rejected the God of the Eastern Rite. His conversion forced him to sell all landholdings, and as further punishment, Ustinow was sent into exile to Germany in 1875. In Württemberg, he was granted German citizenship and the noble title of Baron von Ustinow. During his years in Germany, he became financially involved with members of the German Temple Society in Jaffa. Ustinow had visited Jaffa several occasions since 1862.

\footnotetext{
${ }^{6}$ Elia 1993, 66; 1997, 87; 2009, 240.

${ }^{7}$ Carmel 1978, 297; Dudman \& Kark 1978, 85-86; Eisler 1997, 105; Shay 2009, 8.
} 


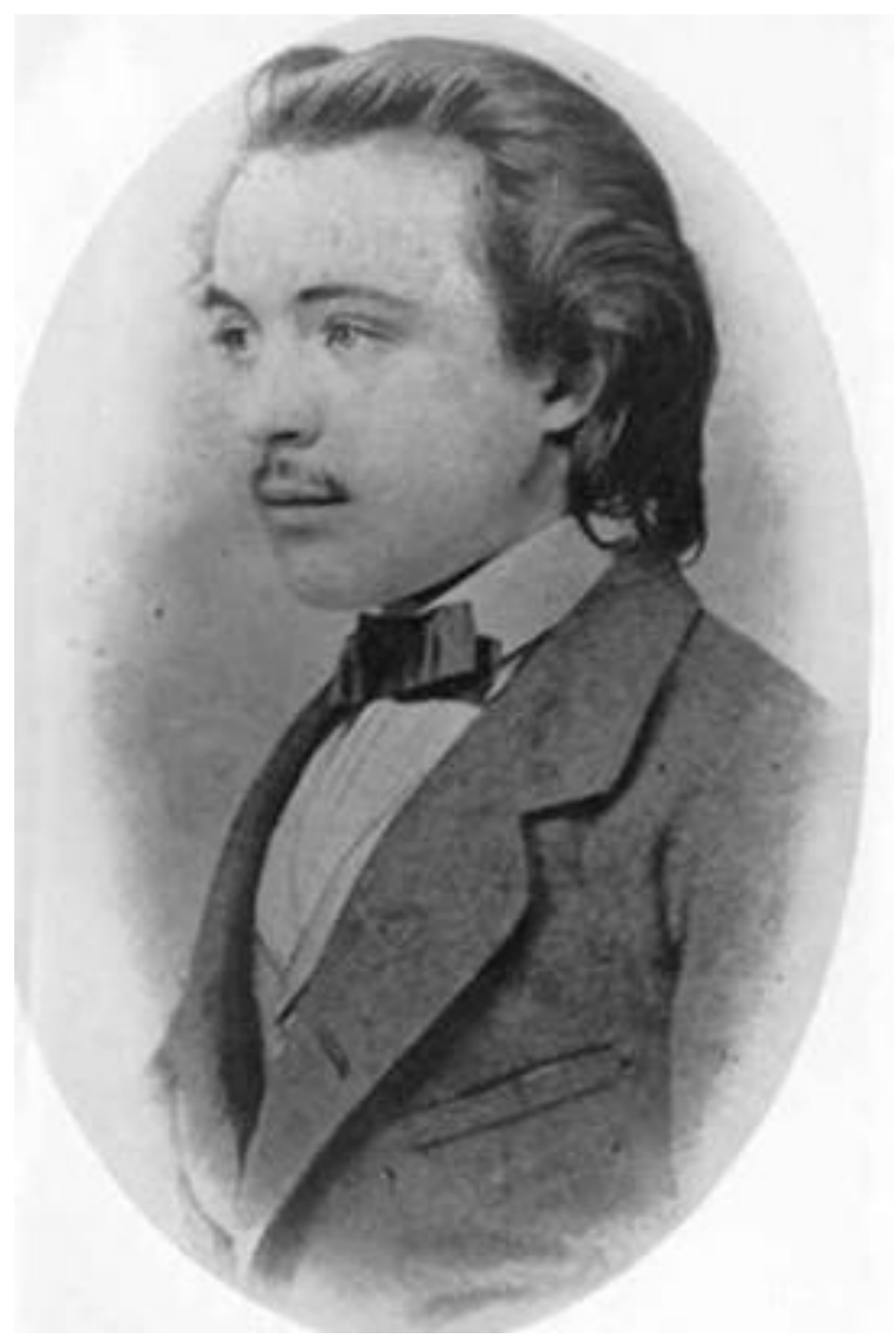

Fig. 1 Plato Grigorievich Ustinov (1833-1920/21) as a young man. Photograph: (C) Nadia Benois Ustinov, 1973: Klop and the Ustinov family, p. 35.

The Holy Land fascinated him, and his motivations for settling in the area, buying up lands and eventually collecting antiquities were later attributed by relatives to his longing to walk where Jesus had walked, to see the well-known places from the Bible and experience the beauty of the landscape.

Ustinow's involvement with the German Temple Society while living in Germany also contributed to his reverence for antiquity. Since the early eighteenth century, German scholars had played a dominant role in establishing classical studies. These academic circles adopted a stylistic analysis of art and artefacts as intellectual frameworks for an aesthetic as well as cultural understanding of ancient societies. By Ustinow's time, classical archaeology and art history had evolved into institutionalised academic disciplines with a scientific basis. Excavated objects became popularised 
historical sources of distant eras which allowed archaeologists and collectors of antiquities to interact with their environments and relate to the past. After joining the German Society for the Exploration of Palestine (Der Deutschen Verein zur Erforschung Palästinas) in 1879, Ustinow allowed the Society to hold annual meetings and conferences in his private home, the Hôtel du Parc (Fig. 2).

We learn something of Ustinow's character and attitudes towards antiquities from two biographies that focus on the extraordinary life of his eldest son, Jona 'Klop' Ustinov, who was a British spy during the period of the Nazi regime in Germany. The artist Nadia Benois Ustinov, Plato's daughter-in-law, wrote Klop and the Ustinow Family. Another account, by the journalist Peter Day, is The Bedbug: Klop Ustinov, Britain's Most Ingenious Spy.

It is unclear whether Nadia Benois Ustinov ever met Plato Ustinow, or if she only knew him through Jona's accounts of his father. Still, she describes him as a conservative 'man of high religious morals, but with a complete lack of modesty':

\begin{abstract}
He led his own life, pursuing his own interests: reading, studying, arranging and rearranging his archaeological collection...I think Plato Grigorievitch was altogether not concerned with the impression he created. Most people simply did not exist for him. When his wife received guests, he retired to his rooms and did not appear again until they had departed. The only people he liked to see were the Benedictine priests and such like, who were scholars of antiquity and with whom he could have long and serious talks on his favourite subjects. ${ }^{8}$
\end{abstract}

Based on a few of Nadia Benois Ustinov's descriptions mentioning his collecting habits, it becomes apparent that Ustinow saw his collection of antiquities as part of a social calculus. By aspiring to the intellectual interest in Classics adopted by monks and ecclesiastical leaders, Ustinow could identify himself as a procurer of the past and custodian of Western scholarly ideals. From Peter Day's account we know that Ustinow's academic fascination with Classics was not just restricted to material culture, but also included linguistics: ${ }^{\circ} \mathrm{He}$ (Ustinow) became an expert in ancient languages, such as Amharic, Greek, Latin and Hebrew'. 'As an aristocrat, Ustinow was educated according to upper-class norms that associated classical antiquity with 'high culture', synonymous with sophistication and intellectual refinement. Such attitudes had played an important role in the traditional educational authoritarianism of the European elite since the sixteenth century. ${ }^{10}$ Ustinow's inherited wealth, as well as his social and political position, ensured that he never had to work to earn a living, and he therefore had time for scholarly pursuits and cultivation.

\footnotetext{
${ }^{8}$ Benois Ustinov 1973, 32 and 35.

${ }^{9}$ Day 2015.

10 Wes 1992, 40; Torlone 2014, 15; Hardwick 2018, 16.
} 


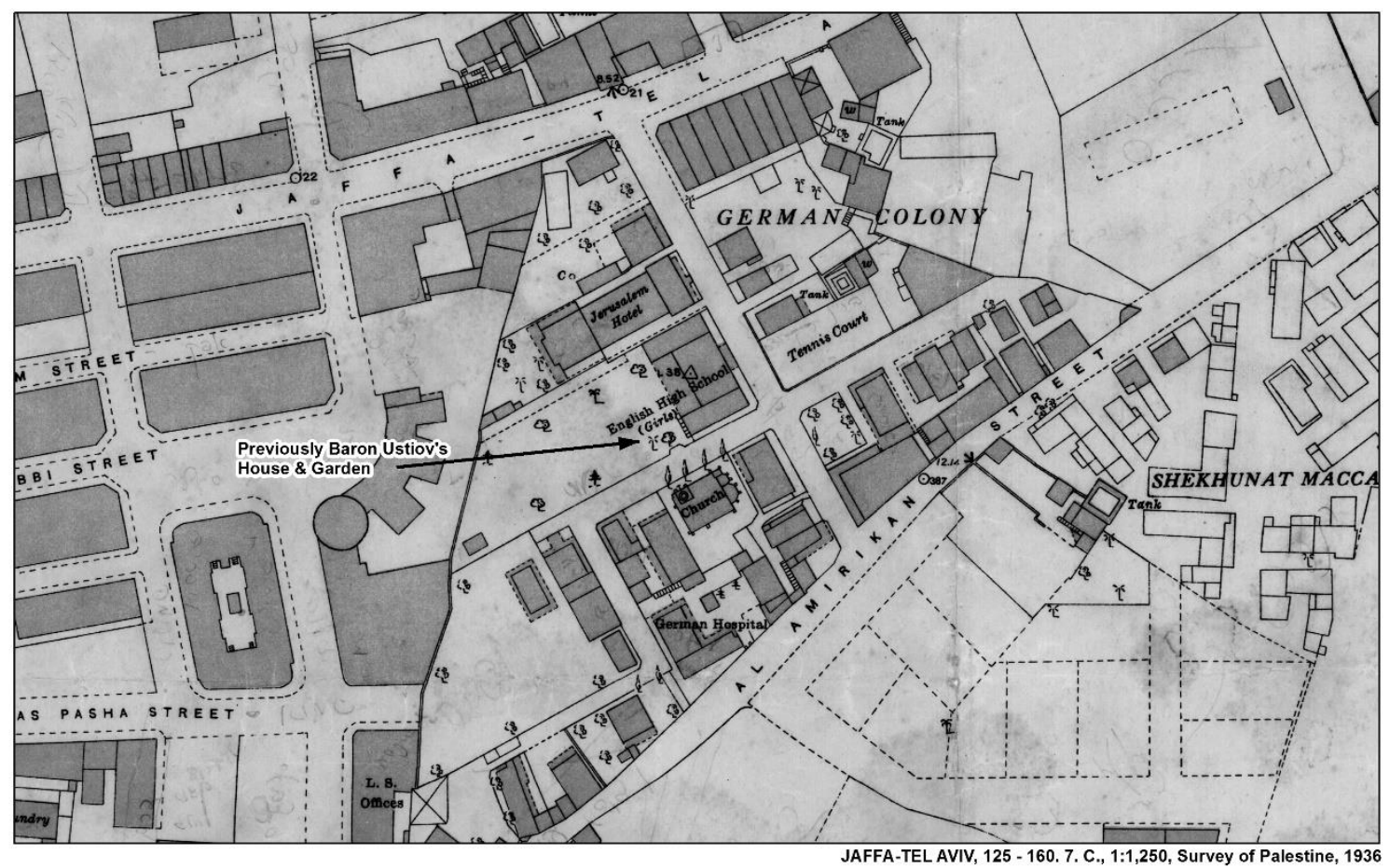

Fig. 2 Map of the German colony in Jaffa showing the position of Ustinov's Hôtel du Parc. Photograph: (C) Survey of Palestine 1936.

By 1913 Ustinow had exhausted his entire fortune and faced personal bankruptcy. With Europe and the Middle East on the brink of war, Ustinow was forced to sell his properties in Jaffa and Jerusalem, as well as the collection of antiquities.

The departure from Jaffa for London is described in the autobiography written by his grandson, the famous British actor Sir Peter Ustinov: 'he packed up his belongings, including his enviable collection of Greek, Roman and Egyptian antiquities and the last remaining suitcases full of money'. ${ }^{11}$ These events undoubtedly influenced why Ustinow sought to sell his collections to several well-established European museums. After negotiating with the British Museum without success, he moved on to Paris and Berlin, and offered the collections to possible buyers, but the attempts failed. He then decided to dispatch his collection to Russia after having been granted special permission to return by Tsar Nicholas II, although the precise details surrounding the movement of the Ustinow collection are still unclear.

However, having been stored in crates between 1913 and 1917, the collection was sold at some point when the Baron travelled from Stockholm to Saint Petersburg. Since the artefacts ended up in Norway, it is reasonable to

${ }^{11}$ Benois Ustinov 1973, 55; Ustinov 1998, 9-10. 
presume that it never arrived in Russia. Therefore, the information provided by his family and other similar narratives demonstrates that the status of archaeological objects at Ustinow's time was yet to be defined. On the one hand, they were understood as commodities, and on the other, as collectable artefacts of academic interest. ${ }^{12}$

Considering this, Ustinow's motives for collecting antiquities may seem ambiguous, but one of his interests was quite possibly rooted in their potential commercial value. Although he considered the items to be his personal possessions, it would be misleading to characterise his approach to archaeological material as ignorant or insensitive. Ustinow was a collector of his time. He represents a period that was essential to the development of archaeology as a field of study in which archaeological objects were organised systematically according to typologies and relative chronologies, and displayed or archived according to the standards of contemporary museum collections.

\section{Western struggles over the Palestinian past and the commodification of material culture}

The land of ancient Palestine today includes modern Israel, Gaza, the West Bank and Jordan. Ancient Palestine is of great historical and archaeological significance. This was the land in which the Bible was written, where the biblical stories originated and where the people of Israel and Jesus lived..$^{13}$ The sites of Ubeidiya, just south of the Sea of Galilee and Wadi Qalkha in modern Jordan, with artefacts and tools dating back to the earliest Palaeolithic inhabitants around 1,000,000 BC, attest to early human activity in these regions. ${ }^{14}$ The pre-classical city-states of Early Iron Age Palestine, Jericho, Ekron, Gath, Ashdod and Ashkelon are famous from the Bible as places inhabited by ancient populations such as the Canaanites, Hebrews and Philistines. ${ }^{15}$ Neo-Assyrian, Neo-Babylonian, Persian and Hellenistic cultural influence on ancient Palestine emerged in the mid-ninth century $\mathrm{BC}$, and lasted until Alexander the Great conquered the region in $332 \mathrm{BC} .^{16}$ The most significant events in Jewish history recorded in the Hebrew Bible occurred during these centuries. The establishment of the Kingdom of Judah under David, the building of the Jerusalem Temple by Solomon and the Babylonian Exile and return were key events in the formation and history of the Israelite nation-state. It is in this context that we take up the complexities surrounding the commodification of material culture and the insertions in social structures.

During the 1840s, European industrial capitalists (especially from nations such as Great Britain, France, Imperial Russia, Austria-Hungary and Prussia/Germany) sought to legitimise their power in the region by claiming ownership of trade routes and resources previously held by the declining

\footnotetext{
12 O’Keefe 1997, 53; Cuno 2008, 6; Ulph 2011, 110; Lucas 2018, 232.

${ }_{13}$ Charlesworth 2006, 21; Davies 2008, 67; Magness 2012, 1-7.

14 Opdyke et al. 1983, 375; Rast 1992, 47-54, 72-74; Gaudzinski 2004, 65-75.

15 Cohen 2001, 7-8; Noll 2001, 154; Killebrew 2005, 156-159; Shai 2009, 15-17.

16 Teissier 1984, 33-45; Miller \& Hayes 1986, 437; Becking 2005, 3-8.
} 
Ottoman Empire. ${ }^{17}$ Palestine in the mid-1800s also experienced large waves of European immigrants. Several religious minorities, such as Jews, Muslims, Eastern Christians and the German Protestant Temple Society, journeyed to Palestine, some in order to escape the ongoing persecution in their homelands. These groups established urban communities, setting up schools, hospitals, businesses and agricultural production in Jerusalem, Jaffa and Haifa. ${ }^{18}$ At the same time, the colonists also developed an interest in the archaeological heritage of Palestine. Western institutionalisation of ancient Palestinian culture saw the settler communities engaging in large, haphazard and unsystematic archaeological excavations, and in the looting and trading of antiquities. ${ }^{19}$ Although the pillaging of sites and objects caused a major conflict between economy and ethics, Western patrimonialisation led to the establishment of pioneering Ottoman legislation to control and protect the Palestinian cultural heritage.

The era saw the movement of objects from their places of origin into private collections. While archaeologists, scholars and scientists mainly represented Western thought, collecting ancient artefacts and historical documents became a profitable occupation among missionaries, diplomats and wealthy businessmen. ${ }^{20}$ This form of cultural imperialism encouraged European intellectuals to seek and preserve material remains from the ancient Orient, arguing that classical antiquities did not belong solely to local history and culture but were the foundation stones of European civilisation. ${ }^{21}$ However, Western exploration and eagerness to acquire antiquities were brought into direct conflict with Ottoman authorities in Palestine. In 1884, the Ottoman government passed a new set of laws on antiquities, which, for the first time, regulated and protected all issues concerning archaeological sites and objects. ${ }^{22}$ These laws also established state ownership of antiquities discovered on Ottoman soil, and prevented foreign powers from plundering the rich Palestinian heritage.

Still, these policies did not halt the acquisition of unprovenanced antiquities. Instead, the effort to form the past into a legacy for the present also resulted in questions about value and significance. To satisfy the demands of collectors, both treasure hunters and antiquities dealers raided and destroyed ancient heritage sites. ${ }^{23}$ Poverty and conflict coupled with plentiful archaeological resources provided an environment where material culture was perceived as capital and a means of personal enrichment. Such competing agendas created complex relationships that challenged the ethical implications of ownership, national value and treatment. At the same time, these power

\footnotetext{
${ }^{17}$ Hinsley 1989, 79-96; Shay 2009, 2; Badem 2010, 46-50.

${ }^{18}$ For excellent commentaries, see Goldman 2004, 108; Kark 2004; Waxman 2019, 33

${ }^{19}$ Mackenzie \& Green 2009, 155; Yates 2015, 71-84; 2016, 173-186

${ }^{20}$ Kark 1984, 357-384; 1994, 139; Ben-Ghedalia 2009, 11-14.

21 Sader 2012, 59; Paine 2013, 52; C,elik 2016, 43.

22 Maffi 2010, 67; Pravilova 2014, 187.

${ }^{23}$ Shaw 2003, 36-37; 2010, 56; Sader 2012, 60.
} 
struggles over objects also led to tension between the status of artefacts as commodities and as cultural property. ${ }^{24}$ While culture is shared, commodities are usually private property, but cultural property embodies the values and traditions of a community. ${ }^{25}$ For example, archaeologist Colin Renfrew discusses how the previous unregulated marketplaces of antiquities, traders and private collectors damaged knowledge of sites and objects. By capitalising on an uncontrolled outflow of antiquities, and ignoring their ethical acquisition responsibilities, nineteenth-century understanding of archaeological artefacts considered antiquities as archival evidence for Proto- and Pan-European cultures, as well as the property of private collectors who regarded themselves as experts of archaeology and ancient history. ${ }^{26}$ From this perspective, professor of archaeological heritage David Gill and archaeologist Christopher Chippindale argue that nineteenth-century private collectors asserted their proprietary rights to cultural objects through intensive import and export. Over time, such activities consequently contributed to the destruction of archaeological context, but also any evidence supporting licit provenance. ${ }^{27}$ In the process of establishing ownership of antiquities, archaeologist Neil Brodie addressed the role of commodification as a principal factor in the art auction system. During the late-1800s, private collectors were not unified by a common set of intellectual, aesthetic or ethical dispositions, nor by social or economic circumstances. Although, while collecting antiquities provided a source of capital for some, others saw cultural objects as an opportunity or as the latest fashion in interior decor. ${ }^{28}$

\section{Collecting, owning and selling cultural heritage}

The question of how Ustinow became one of the nineteenth century's most prolific collectors of Palestinian antiquities is a debate rooted in lawful ownership, preservation and identity of cultural objects. The Ottoman law of 1884 was passed as a measure to ensure that artefacts from the Ottoman Empire remained within its borders. Under the law, all foreign excavators had to apply for permission to excavate, and all antiquities recovered during excavations were to be transferred to the Imperial Museum in Constantinople. Only artefacts that were labelled as non-essential to the cultural heritage of the Ottoman Empire were returned to the excavator or landowner for study, analysis and sale. Although cultural heritage was the property of the Empire, local populations could still buy, sell and exchange artefacts within Ottoman territories.

\footnotetext{
${ }^{24}$ Harris 2005, 30; Bruchac 2014, 2067-2077; Walker Tubb 2014, 58.

25 Shaw 2003, 38; Smith \& Martin Wobst 2005, 4-5; Cuno 2008, 2-3; Layton \& Wallace 2008, 46-47; Bazley 2010, 110.

${ }^{26}$ Renfrew 1993, 16-17; 2000, 27-28, 39.

27 Gill \& Chippindale 1993, 629.

${ }^{28}$ Brodie 2006, 56-57. See also useful contributions by Ziadeh 1993, 6-7; Attila Aytekin 2009, 935-951; Kark 2017, 101-119.
} 


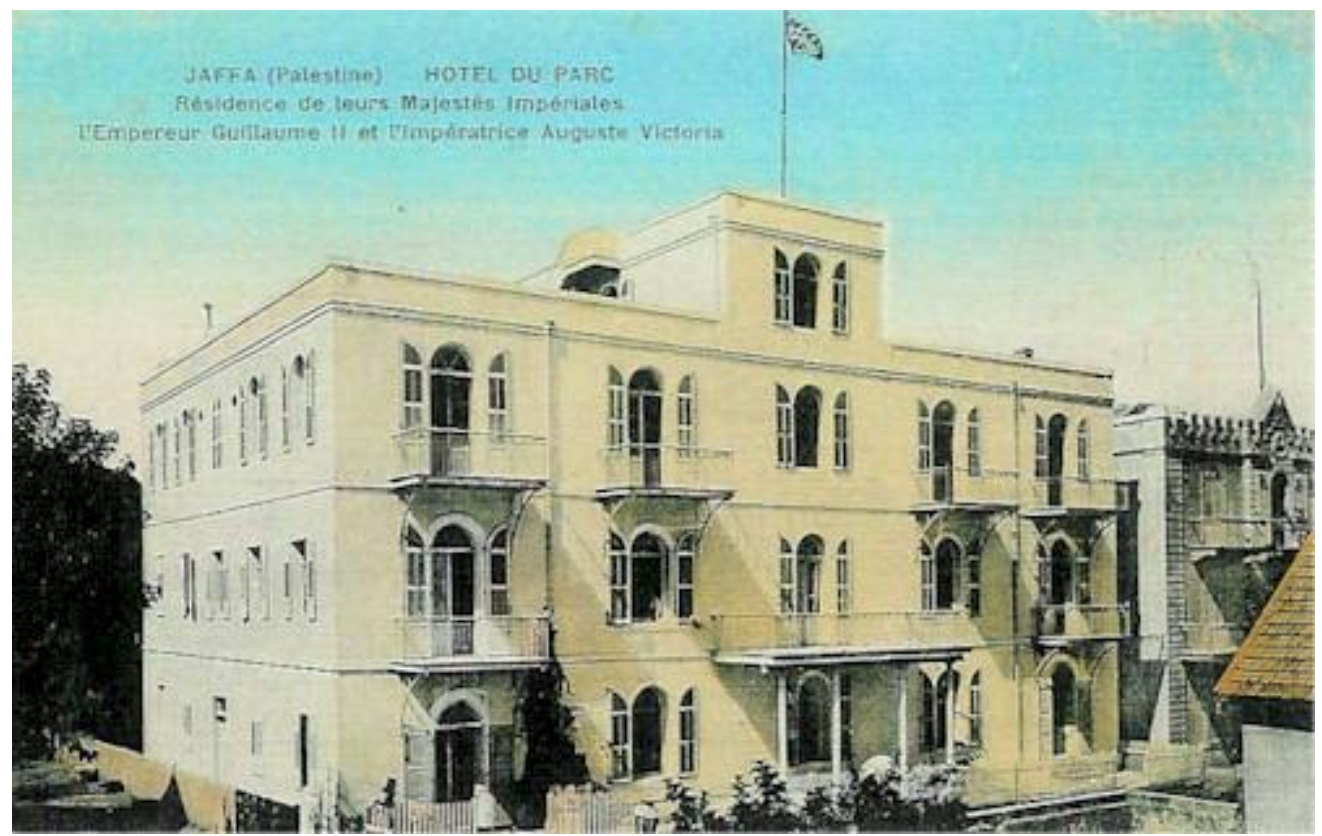

Fig. 3 Postcard depicting Hôtel du Parc in 1898. Photograph: (C beitimmanuel.org.

In practice, enforcement of this law was impossible. The Ottoman Empire was so vast that its government did not have enough officials to oversee and implement these regulations. To complicate matters further, the Ottoman government also deployed artefacts as cultural capital in the form of bribes and gifts to forge political alliances and cultivate diplomatic relationships. This was the case with the close association between Sultan Abdulhamid II, Emperor Franz Joseph I and Kaiser Wilhelm II. The Sultan himself ignored the law when it suited his diplomatic goals, allowing the free movement of archaeological objects in return for political gain from influential Westerners. ${ }^{29}$ The Kaiser visited Ustinow's collection of antiquities in 1898 while lodging at Hôtel du Parc during a royal visit to Palestine. This kind of encounter might explain how Ustinow was allowed to collect and display ancient artefacts (Fig. 3). ${ }^{30}$

We do not know the exact circumstances under which Ustinow began his career as a collector of antiquities. However, when he attempted to sell his collection to the British Museum in 1913, he admitted that he began buying and collecting artefacts shortly after settling permanently in Jaffa in 1878. Objects from ancient Phoenicia were his main interest, and collecting antiquities originally emerged from a personal aspiration to own and display Phoenician inscriptions in his home. ${ }^{31} \mathrm{He}$ also acquired Greek, Roman and Egyptian antiquities as well as Arab coins and Bedouin jewellery. Family members believed that Ustinow mainly bought antiquities from poor local

${ }^{29}$ Gibson 1999, 115-143; Shaw 2003, 116-117; Kersel 2010, 85-87.

${ }^{30}$ Jones 1913; Tveit 2000, 163.

31 Benois Ustinov 1973, 27-28; Shay 2009, 7. 
Arab farmers. ${ }^{32}$ His Protestant concept of charity made him feel morally compelled to assist them financially. ${ }^{33}$ However, such speculations become complicated when considering the ethnic identity of these so-called 'poor local Arab farmers'. As in other artefact-rich territories, peasants often found coins, statues, pottery and ancient marble while working in Palestine's countryside. If drought, economic crisis or inflation forced these impoverished smallholders to seek out dealers or an art market, the Ottoman law did not prohibit farmers from engaging in selling or trading cultural objects.

Such acts were not uncommon. The same year Ustinow established himself at Jaffa, the 'beşlik affair' of 1878 saw the collapse of the local financial markets in both Jaffa and Jerusalem. Acute poverty and legal restrictions imposed on poor local farmers resulted in artefacts finding their way on to the antiquities market or ending up in the homes of private collectors. Ustinow also regarded purchasing antiquities as an ethical responsibility to prevent their desecration: 'I noticed that the Moslems destroyed Jewish and Christian antiquities and arts. For example, they removed the crucifix in different monuments and more. They crushed objects with artistic value. This led to the decision of collecting and saving as many objects as possible from destruction and demolition'. ${ }^{34}$ Ustinow's descriptions of 'Moslems' as destructive looters of antiquities reflect attitudes that viewed owning archaeological artefacts as synonymous with the protection and conservation of material culture. ${ }^{35}$

\section{The private exhibition hall at Hôtel du Parc}

We have little concrete evidence of how Ustinow's collection of antiquities was organised and displayed at Hôtel du Parc. Nor do we have any clear idea of the connections between the different spaces and the positioning of the objects or their visual relationship to each other. Still, what we do know is that Ustinow gradually transformed his collection of antiquities into an attraction during the 1880s. ${ }^{36}$ Hôtel du Parc seems to have served as a multi-purpose structure. It functioned as the private residence of Ustinow, his family (second half-Jewish wife Magdalena Hall and four children) and his collection of antiquities, but also as a fashionable hotel for wealthy politicians and aristocrats, and even as a hospital equipped with thirty beds for Jewish and Protestant refugees in need of free medical treatment (Fig. 4). ${ }^{37}$ However, in 1895 Ustinow decided to convert large sections of Hôtel du Parc into a public exhibition hall to accommodate his private collection of antiquities as well as a botanical garden design by Bekhōr Nissīm 'Elhādīf. ${ }^{38}$ The latter became

\footnotetext{
32 Benois Ustinov 1973, 55; Ustinov 1998, 9-10.

${ }_{33}$ Berczelly 1997, 30-39; 1999, 4-15; 2004, 275.

${ }^{34}$ Skupinska-Lovset 1976, 17.

35 Brumfiel 2003, 205-223; Watkins 2005, 429-449; Atalay 2006, 269-277.

36 Carmel 1973, 44; Vogel 1993, 156; Perî 2003, 148-155; Perry \& Lev 2007, 125-129.

${ }^{37}$ Carmel 1983, 212; Carmel \& Eisler 1999, 80-82; Tveit 2000, 163; Shay 2009, 4.

${ }^{38}$ Eisler 1997, 106-108.
} 


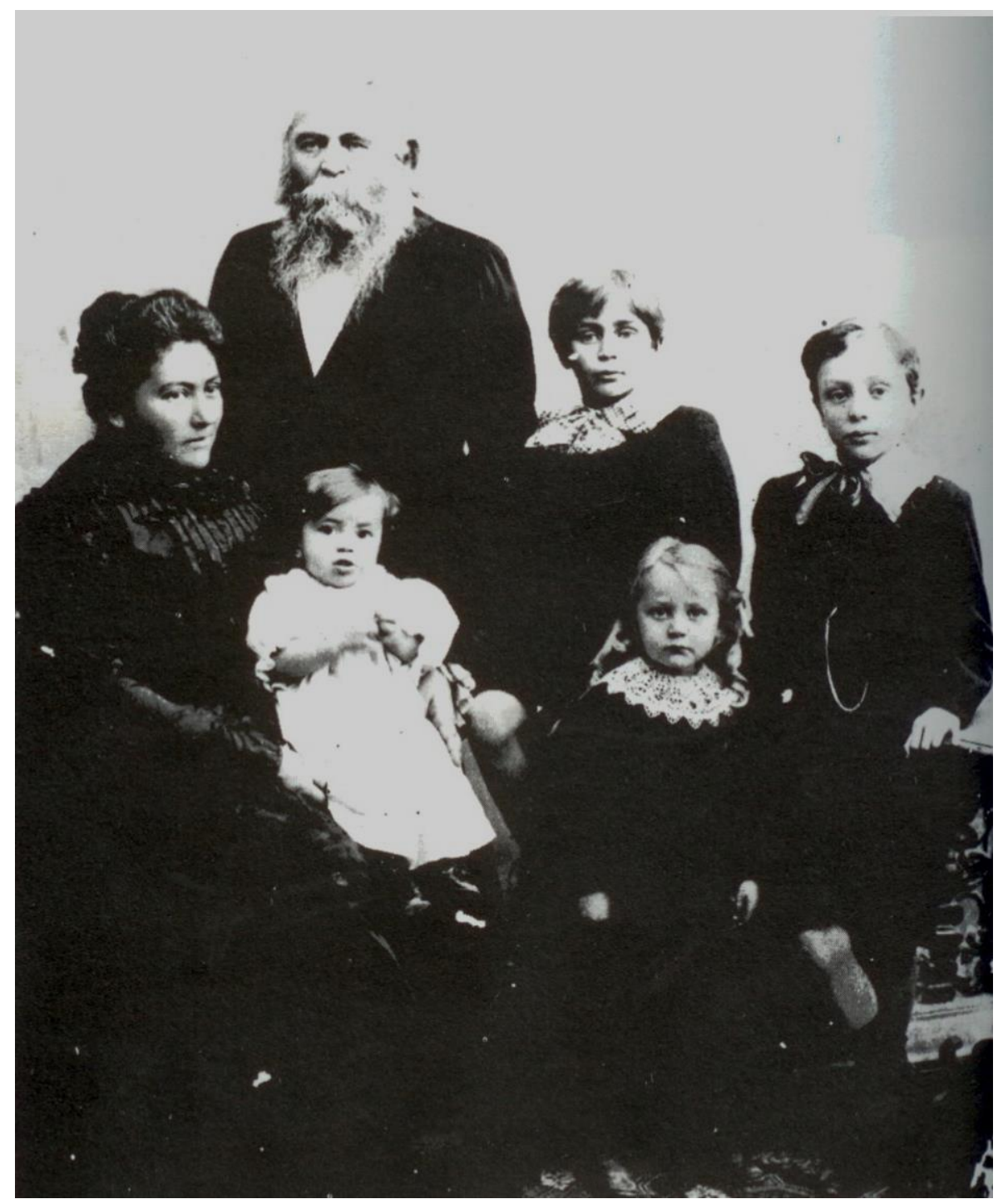

Fig. 4 The Ustinov family. Photograph from: (C) Museum of Cultural History, University of Oslo. Inv. C47028.

known as the first graduate of the Jewish agricultural school in Palestine, Miqve-Yisrael. In addition to equipping the garden with unique trees and strikingly beautiful flowers, Elhādíf also installed a small zoo that contained about twenty different parrots, cockatoos, flamingos and pelicans as well as a large variety of fascinating monkey species. This botanical garden was the first example of a public conservatory with cultivated exotic plants in Palestine which aimed to both educate and enchant visitors (Fig. 5). We also have depictions of Hôtel du Parc in later fiction, specifically, the novel Two Tales: Betrothed \& Edo and Enam by the Israeli author Samuel J. Agnon, winner of the 1966 Nobel Prize for literature. Agnon painted an amusing picture of the ageing Ustinow together with his favourite parrot from 


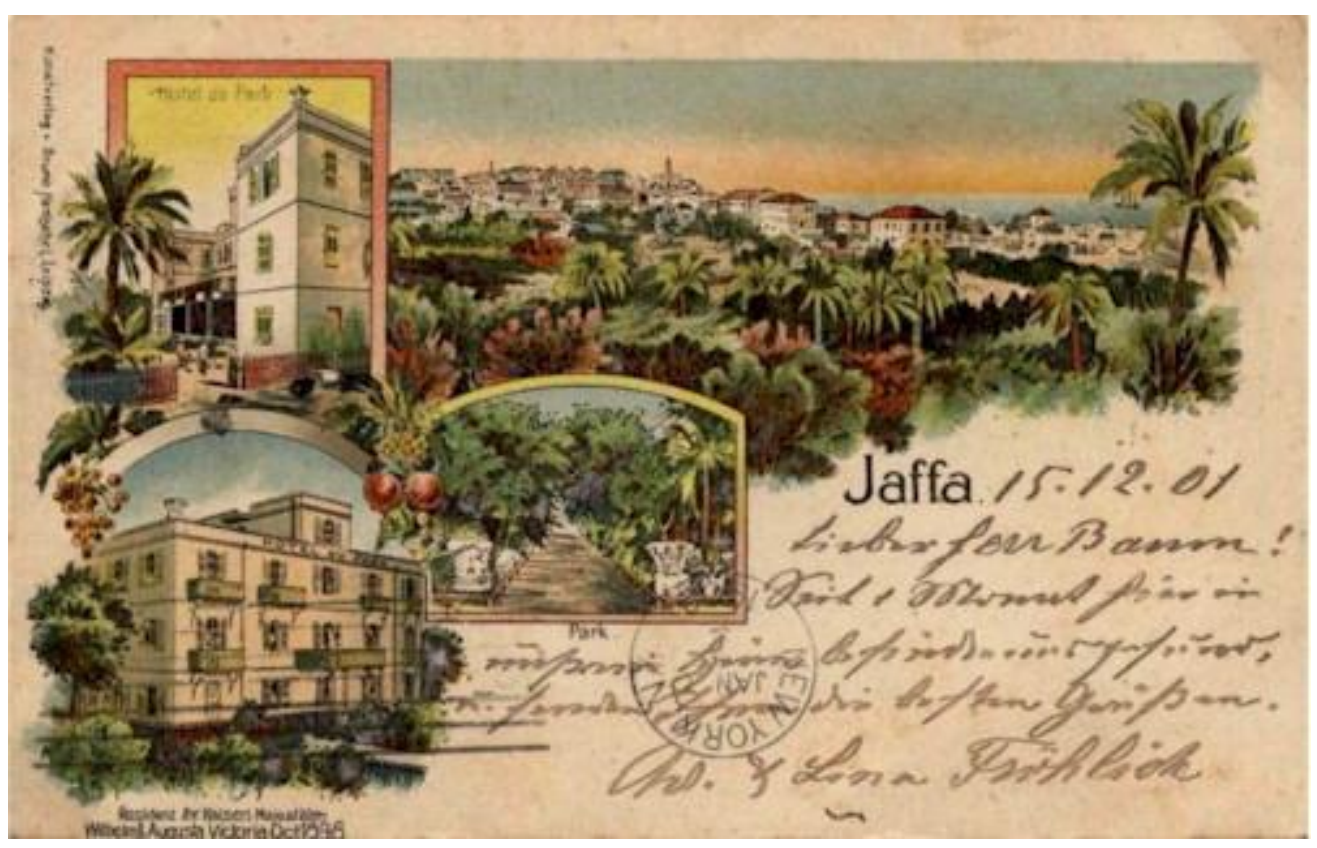

Fig. 5 Postcard from 15.12.01 depicting Hôtel du Parc with the surrounding gardens. Photograph from: C) beitimmanuel.org.

the zoo wandering the botanical garden, in conversation with the novel's main character Dr Rechnitz:

\begin{abstract}
A strange shriek interrupted the train of Rechnitz's thoughts. The parrot, which on the evening before last has perched in his cage at the hotel imitating the jackal's scream, was now in the garden answering the sound of the striking clock. Before him stood the old Baron, dressed in white, with a tropical sun-helmet on his head. The Baron was holding out an apple and the parrot, standing on one leg, extended the other, snatched the apple and pecked at it. 'Schmeckt's, Herrchen?' the Baron asked. The parrot shook his hooked beak and cried 'Schmeckt Herrchen?' 'A fine bird," said the Baron to Rechnitz. 'I bought it from a hunter who had caught it to eat. There are places, you know, where they eat parrot-meat.' 'Verflucht' he called to the bird. 'Verflucht' it answered back. The Baron laughed and wagged his finger at the. 'Verflucht,' he said to it, 'Verflucht, you mustn't say Verflucht!". The parrot replied with a shriek, "Verflucht! Verflucht!? 39
\end{abstract}

Ustinow was not an archaeologist. He lacked both an academic degree and practical excavation experience in the field. Therefore, collecting and displaying antiquities, as well as the construction of an exhibition hall where the past legitimised both art and science, generated self-enclosed purpose. Ustinow used his collection as a tool not just to help increase and refine his own knowledge of ancient Palestinian history and archaeology, but also to

\footnotetext{
${ }^{39}$ Agnon 1966, 77.
} 
attract scholars. ${ }^{40}$ It is likely that Ustinow's ambitions were first and foremost connected to recognition. Then ancient and valuable possessions in his private collection became crucial to his self-value, serving as symbolic 'extension of self', attesting to his personal judgements, education and tastes. ${ }^{41}$

Ustinow's collection of antiquities at Hôtel du Parc was open and available to academics as well as to guests who were interested in studying ancient artefacts. ${ }^{42}$ The French archaeologist and Dominican friar LouisHugues Vincent visited the collection on several occasions between 1904 and 1908 to study funerary busts and epitaphs from the ancient burial grounds in Jaffa. In the prestigious Revue Biblique, Vincent described the relaxed and vibrant environment Ustinow had managed to create within his self-made exhibition hall. ${ }^{43}$ The German architect, archaeologist and Protestant missionary Conrad Schick also spent time inspecting many of Ustinow's items. He reported back to his readers of Palestine Exploration Fund Quarterly Statement detailing some of the peculiar and unusual objects that Ustinow had among his collected antiquities:

\begin{abstract}
Philistine mice and other antiquities: Some metal figures of mice in the collection of antiquities of Baron Ustinow at Jaffa: The Baron has about half-a-dozen creatures made from white-looking metal, not silver, but harder than pewter or zinc. They were found by the peasants in the land of the Philistines and represent mice. When I saw them, at once I Samuel, vi. 4, 5, came into my mind. These figures are not solid, but half relief, and pressed out from a flat piece of metal. They are without a tail, but have a hole into which a string could be fixed by which to hang up the figures as an amulet. The five golden mice which the Philistines put as an atonement with the Ark of the Covenant when sending it back, as related in I Samuel, vi.4, 11, were perhaps such amulets. This discovery is most interesting. In the same collection were other interesting pieces. A half-dozen curious figures made of hollow copper, representing a kind of serpent with a dragon's hand, with two long ears, and in its sharp, beak-shaped mouth a falling ball. It is cast, not beaten, work, but no two were cast in one form of model. Also, a block of reddish hard stone, on which is carved the figure of a woman with two wings in a recumbent position. The hands and feet, instead of ending in fingers and toes, end with fish-tails. Close to the feet, is the word EYTYXHC.44
\end{abstract}

The Anglican canon and antiquarian James Edward Hanauer recorded and interpreted some of Ustinow's grave inscriptions. By applying the method referred to as a 'squeeze', Hanauer used wet paper to capture the true moulds of stone surfaces which he could translate. These impressions received much

\footnotetext{
40 Formanek 1994, 331.

${ }^{41}$ Belk 1994, 317-322; Oz 2000, 11.

42 Skupinska-Løvset 1976, 18.

43 Vincent 1904, 84; 1908, 125.

${ }^{44}$ Schick 1893, 557-631.
} 
academic attention and were published together with the French archaeologist Charles Clermont-Ganneau's excavation report on the ancient necropolis of Jaffa. ${ }^{45}$ American archaeologist and founder of the American Journal of Archaeology, Arthur Lincoln Frothingham, Jr collaborated with Ustinow in further analysing some of the funerary epitaphs:

\begin{abstract}
Baron Ustinoff had added to his collection of antiquities at Jaffa a slab with a Latin inscription brought from Ascalon. It begins with MAGISTER FILIPVS, the name of the architect: there follows, on the second line, his designation as de camera regis...showing that he was the official architect to a king who is supposed by Baron Ustinoff to be Richard Cæur de Lion. On the third line is fecit hoc opus, while the fourth gives the part of the fortifications he erected, describing them as from a point unknown (the inscription is broken here up to the gate where the inscription was evidently placed. The inscription is broken away in the lower left-hand corner. ${ }^{46}$
\end{abstract}

Several cultural objects in Ustinow's collection of antiquities were documented through international academic journals. Although such reviews encouraged further research and generated educational materials, these publications largely catered to Western scholarly interests. By opening up his collection of antiquities to archaeologists and historians, Ustinow was able to categorise the cultural objects housed at Hôtel $d u$ Parc chronologically, which became a very useful feature of the collection in terms of economic value. Ordering the material according to this linear view was a cornerstone of social evolutionism and part of a long-standing Western ontology. Within archaeology and art history the inside-outside schema was most clearly expressed and elaborated through the theoretical frameworks of social evolutionism founded upon elite associations with ideological antiquarianism. This understanding of material culture played a significant role in Ustinow's attitudes towards the objects when he attempted to sell his collection in 1913.

\title{
The Ustinow collection reaches Norway
}

After decades of collecting and buying archaeological artefacts, Ustinow left Palestine along with his antiquities, which were packed up in storage crates which he took with him on his travels across Europe. Ustinow's constant spending had also taken its toll on his personal finances. Realising that a profit could be made by selling ancient Palestinian heritage to foreign buyers, Ustinow met the demands of a growing Western interest in cultural objects. He first tried to sell his collection to the British Museum, but when he could not obtain a satisfactory offer, he tried the Louvre in Paris. After these failed attempts, Ustinow's collection of antiquities was bought by three Norwegians and moved to Christiana (today's Oslo). In 1917 British-Norwegian

\footnotetext{
45 Clermont-Ganneau 1896, 110-123; Skupinska-Løvset 1976, 157-158; Ameling et al. 2014, 36.

${ }^{46}$ Frothingham 1893, 616.
} 
businessman Karl Fredrik Knudsen, banker Johannes Sejersted Bødtker and lawyer Arnold Ræstad apparently met with Ustinow as he travelled from Stockholm to Saint Petersburg to conclude the transaction. By 1918 the cultural objects were auctioned off. Of 1521 items, 420 were purchased by private individuals. The remaining artefacts were either lost or donated to other cultural institutions. As far as we know, Plato Ustinow never knew what became of his collection of antiquities; he died from starvation during the siege of Pskov in $1920 .{ }^{47}$ Since 1940 the Ustinow collection has frequently been moved around between various repositories. At present, a large part of the collection is kept in storage at the University of Oslo. However, a few selected items are on show in current exhibitions at the Museum of Cultural History attesting to the importance and relevance of the Ustinow collections of antiquities (Figs. 6a-c).

\section{Conclusion}

Previous studies on the Ustinow collection of antiquities have struggled with the difficulties behind examining Baron Plato von Ustinow's motives for collecting, and how he became one of the nineteenth century's most prolific collectors of archaeological items from ancient Palestine. In past research, there is a general recognition that the collection represents an intellectual achievement in both its diverse content and its relevance to culture and archaeology. According to contemporary attempts to analyse the history of collecting antiquities, Ustinow's collection is also regarded as a prime example and source for understanding nineteenth-century attitudes towards owning and displaying artefacts from the remote past. In an effort to understand the Ustinow collection in a new light, we have suggested a decolonisation approach that challenges the interconnections between nineteenth-century society and the status of material culture as either shared by communities or privately-owned commodities. A decolonisation perspective allows us to rethink how archaeological items were used in private collections, while the role of a sense of entitlement to heritage objects has also been underlined. The belief that individual Western collectors such as Plato von Ustinow sought antiquities without any motivational forces has been actively contested. Similarly, the emotional attachment to collected items cannot alone account for the deeper physiological relationship between people and things. However, a decolonisation approach to collecting practices and material culture reconfigures the social conditions which lay the foundations for Ustinow's engagement with antiquities and the formation of his collection. Firstly, his social position and personal wealth allowed him to buy, own and display archaeological artefacts within the boundaries of his personal property in Jaffa. Secondly, his personal and political network of contacts within the Ottoman administration permitted him to collect and display antiquities. Thirdly, faced

\footnotetext{
${ }^{47}$ Ustinov 1998, 28.
} 


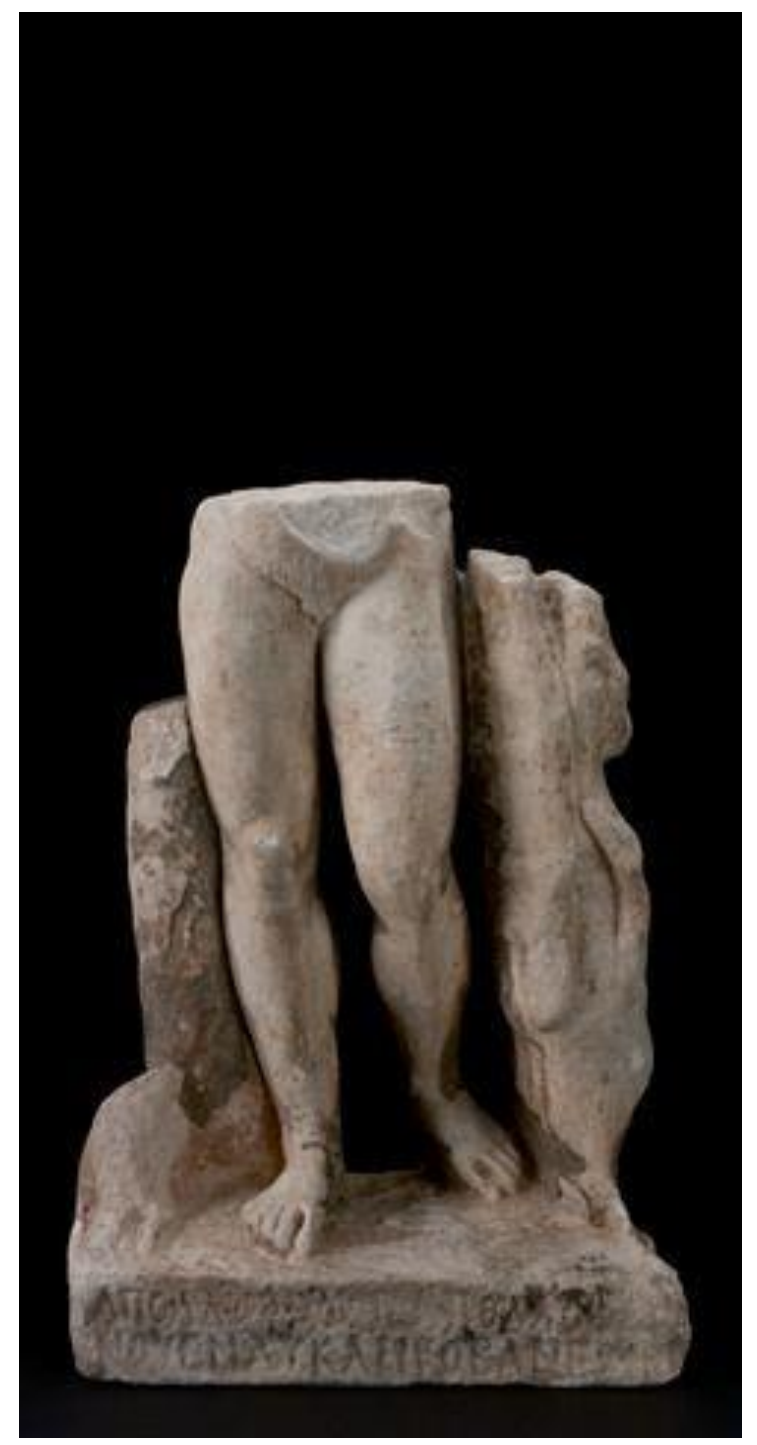

Fig. 6a Statue of Hercules. c. 1-2 AD. From the Ustinow Collection.

Photograph: Museum of Cultural History, University of Oslo C. Inv. C40833.

with a constant supply of cultural objects with no direct interference from the law, Ustinow constructed a private exhibition hall at Hôtel $d u$ Parc and opened it up to a large audience consisting of both scholars and non-scholars. Apart from the significant public interest generated by such a self-made museum, celebrated academics and trained archaeologists also frequented Ustinow's private collection. Such scholarly interest contributed, in part, to a typological dating and classification of numerous objects, many of which were also published in various international journals. 


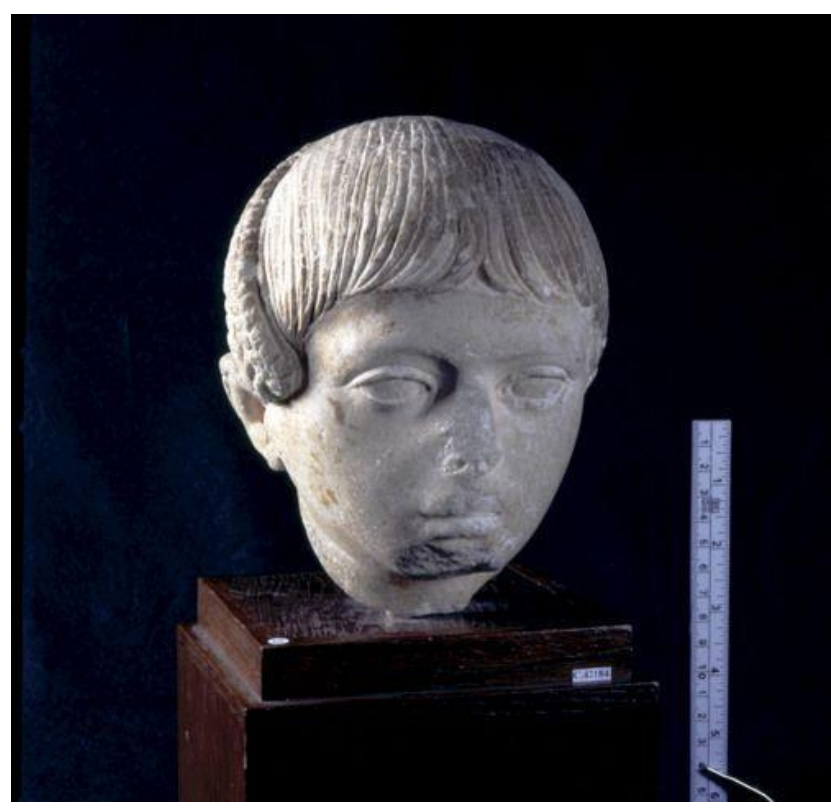

Fig. 6b Marble portrait of a boy. AD 120-130. From the Ustinow Collection. Photograph: Museum of Cultural History, University of Oslo (C. Inv. C42184.

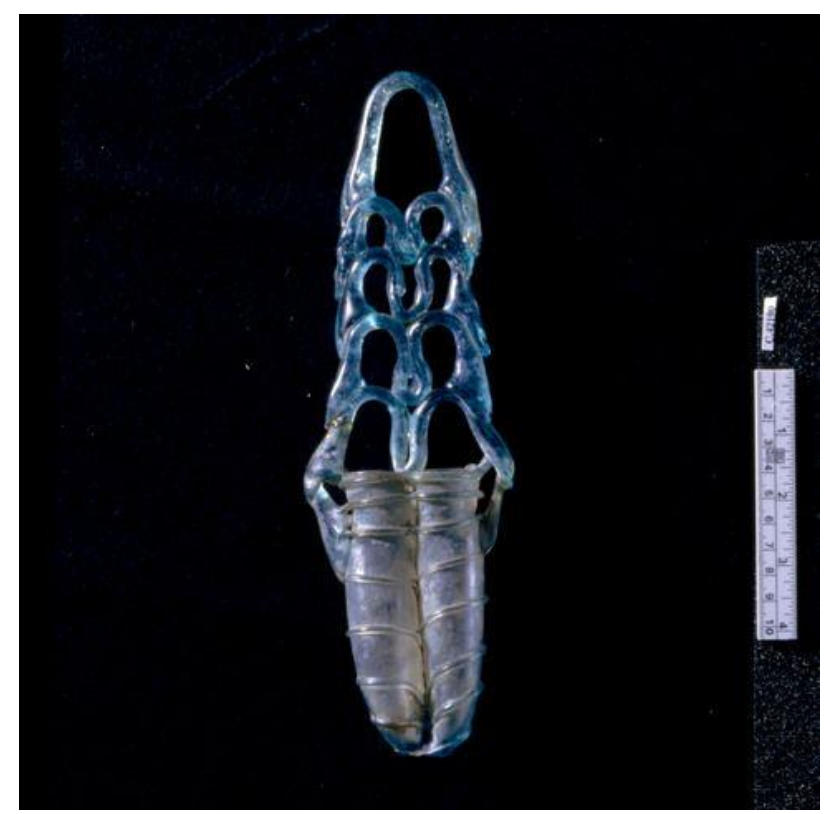

Fig. 6c A double balsamarium. From the Ustinow Collection. Photograph: Museum of Cultural History, University of Oslo C. Inv. C42190.

Professor Ruth Kark

Department of Geography Faculty of Social Sciences

The Hebrew University of Jerusalem

ruthkark@mail.huji.ac.il

Astri Karine Lundgren

Department of Archaeology and Ancient History

Uppsala University, Sweden

astrikalundgren@hotmail.com

Associate professor Laszlo Berczelly

Department of Archaeology, Conservation and History

University of Oslo

laszlo.berczelly@,icloud.com 


\section{References}

Agnon, S. Y. 1966: Two Tales: Betrothed and Edo and Enam, translated from the Hebrew by Walter Lever. New York: Schocken books.

Ameling, W, A. Ecker \& Hoyland. R. 2014: Corpus Inscriptionum Indaeae, Palaestinae: A Multi-lingual Corpus of the Inscriptions from Alexander to Muhammad South Coast: 2161-2648. Berlin: Walter De Gruyter.

Atalay, S. 2006: 'Decolonizing Archaeology', Am. Indian Q 30(3/4): 269-277.

Attila Aytekin, E. 2009: 'Agrarian Relations, Property and Law: An Analysis of the Land Code of 1858 in the Ottoman Empire', Middle East. Stud 45(6): 935951.

Auty, R. \& Obolensky, D. 1976: An Introduction to Russian History. Cambridge: Cambridge University Press.

Badem, C. 2010: The Ottoman Crimean War (1853-1856). Leiden: Brill.

Bazley, T. 2010: Crimes of the Art World. Santa Barbara: Praeger.

Becking, B. 2005: 'We all Returned as One', in O. Lipschitz \& M. Oeming (eds), Judah and the Judeans in the Persian Period, 3-19. Winona Lake: Eisenbrauns.

Belk, R. W. 1994: 'Collectors and Collecting', in S. N. Pearce (ed.), Interpreting Objects and Collections, 317-327. London \& New York: Routledge.

Ben-Artzi, Y. 2006: 'The German Templars in Eretz-Isreal', in A. Baker \& G. Biger (eds), Ideology and Landscape in Historical Perspective: Essays on the Meanings of Some Places in the Past, 83-107.Cambridge: Cambridge University Press.

Ben-Ghedalia, Y. 2009: The Habsburgs and the Jewish Philanthropy in Jerusalem During the Crimean War (1853-6). Jerusalem: The Hebrew University.

Benois Ustinov, N. 1973: Klop and the Ustinov Family. London: Sidgwick \& Jackson.

Berczelly, L. 1997: 'Norges største antikksamling fra middelhavslandene: Ustinow-samlingens historie', Nicolay 72: 30-39.

Berczelly, L. 1999: 'Norges største antikksamling fra middelhavslandene, 2: Hva kan Ustinow-samlingen fortelle?' Nicolay 78: 4-15. 
Berczelly, L. 2004: 'The Tomb of a Prelate from the Crusader Period in Jaffa and Five Fragments of an Opisthographic Marble Slab in the Ustinow Collection in Oslo', ActaAArtHist 18: 275-288.

Brodie, N. 2006: 'An Archaeologist's View of the Trade in Unprovenanced Antiquities', in B. T. Hoffman (ed.), Art and Cultural Heritage: Law, Policy, and Practice, 52-63. Cambridge: Cambridge University Press.

Bruchac, M. 2014: 'Decolonization in Archaeological Theory', in C. Smith (ed.), Encyclopedia of Global Archaeology, 2069-2077. New York: Springer.

Brumfiel, E. 2003: 'It's a Material World: History, Artifacts, and Anthropology', Annu. Rev. Anthropol (32): 205-223.

Carmel, A. 1973: Die Siedlungen der Württembergischen Templer in Palästina, 18681918: Ibre Lokalpolitischen und Internationalen Probleme. Stuttgart: Kohlhammer.

Carmel, A. 1978: Palästina-Chronik 1853-1882. Ulm: Vaas.

Carmel, A. 1983: Palästina-Chronik 1883-1914. Ulm: Vaas.

Carmel, A. 1990: 'Spittler and the Activities of the Pilgrims Mission in Jerusalem', in G. G. Gîlbar (ed.), Ottoman Palestine: 1800-1914: Studies in Economic and Social History, 255-287. Leiden: Brill.

Carmel, A. \& Eisle, E. J: 1999: Der Kaiser Reist ins Heilige Land die Palästinareise Wilhelms II. 1898. Stuttgart: Kohlhammer.

C,elik, Z. 2016: About Antiquities: Politics of Archaeology in the Ottoman Empire. Austin: University of Texas Press.

Charlesworth, J. H. 2006: 'Jesus Research and Archaeology: A New Perspective', in J. H. Charlesworth (ed.), Jesus and archeology, 11-63. Grand Rapids: Eerdmans Publishing.

Ciulisová, I. 2006: 'Art Collecting of the Central-European Aristocracy in the Nineteenth Century', J Hist Collect 18(2): 201-209.

Clermont-Ganneau, C. 1896: 'Archaeological Researches in Palestine During the Years 1873-1874: Notes on Squeezes of Inscriptions in the Baron Ustinow's Collection, Sent by the Rev. J.E. Hanauer', PEFQ 32(2): 110-123.

Cohen, M. 1992: 'Rooted Cosmopolitanism', Dissent (1992): 478-483. 
Cohen, S. L. 2001: Canaanites, Chronologies, and Connections: The Relationship of Middle Bronze IIA Canaan to Middle Kingdom Egypt. Winona Lake: Eisenbrauns.

Cotton, H. \& Eck, W. 2004: 'Lateinischen Inschriften aus der Ustinov Collection in Oslo und ein Opistograph der Damnatio Memoriae des Kaisers Probus', in I. Piso \& C. Roman (eds), Orbis Antiquus: Studia in Honorem Ioannis Pisonis, 48-57. Cluj-Napoca, Nereamia Napocae Press.

Cuno, J. 2008: Who Owns Antiquity? Museums and the Battle Over Our Ancient Heritage. Princeton: Princeton University.

Davies, P. R. 2008: Memories of Ancient Israel: An Introduction to Biblical History, Ancient and Modern. Louisville: Westminster John Knox Press.

Day, P. 2015: The Dedbug: Klop Ustinov, Britain's Most Ingenious Spy. New York: Biteback Publishing.

Dyson, S. L. 2006: In Pursuit of Ancient Pasts: A History of Classical Archaeology in the Nineteenth and Twentieth Centuries. New Haven: Yale University Press.

Dudman, H. \& Kark, R. 1998: The American Colony: Scenes From a Jerusalem Saga. Jerusalem: Carta Jerusalem.

Eisler, E. J. 1997: Der Deutsche Beitrag zum Aufstieg Jaffas 1850-1914: Zur Geschichte Palästinas im 19. Jabrbundert. Wiesbaden: Harrassowitz.

Eisler, E. J. 1999: Peter Martin Metzler (1824-1907): Ein Christlicher Missionar im Heiligen Land. Haifa: Gottlieb-Schumacher-Institut.

Elia, R. J. 1993: 'A Seductive and Troubling Work', Archaeology 46(1): 66-69.

Elia, R. J. 1997: 'Looting, Collecting, and the Destruction of Archaeological Resources', Nonrenewable Resour 6(2): 85-98.

Elia, R. J. 2009: 'Mythology of the Antiquities Market', in J. A. R Nafziger \& A. M Nicgorski (eds), Cultural Heritage Issues: The Legacy of Conquest, Colonization and Commerce, 239-255. Leiden: Brill.

Elina, O. 2018: 'A Passion for Plants: Collections and Power Games in Botany in the Russian Empire From the 18th to the Early 19th Century', Centaurus 60(4): 257-275.

Fiedler, F. 1994: The Story of Faith Missions. Oxford: Regnum Books. 
Formanek, R. 1994: 'Why They Collect: Collector Reveal their Motivations', in S. N Pearce (ed.), Interpreting Objects and Collections, 327-336. London \& New York: Routledge.

Frothingham, A. L. Jr 1893: 'Archæological News', The American Journal of Archaeology and of the History of the Fine Arts 8(4): 557-631. https://www.jstor.org/stable/495888 DOI: 10.2307/495888.

Gaudzinski, S. 2004: 'Subsistence Patterns of Early Pleistocene Hominids in the Levant- taphonomic Evidence From the 'Ubeidiya Formation (Israel)', J. Archaeol. Sci 31(1): 65-75.

Gibson, S. 1999: 'British Archaeological Institutions in Mandatory Palestine, 1917-1948.' Palest. Explor. Q 131 (2): 115-143.

Gill, D. \& Chippindale, C. 1993: 'Material and Intellectual Consequences of Esteem for Cycladic Figures', AJA 97(4): 601-659.

Goldman, S. 2004: God's Sacred Tongue: Hebrew \& The American Imagination. Chapel Hill: University of North Carolina Press.

González-Ruibal, A. 2009: 'Vernacular Cosmopolitanism: An Archaeological Critique of Universalistic Reasoning', in Meskell (ed.), 113-139.

Hardwick, L. 2018: 'Thinking With Classical Reception: Critical Distance, Critical licence, Critical Amnesia?', in E. Richardson (ed.), Classics in Extremis: The Edges of Classical Reception, 13-25. London: Bloomsbury Academic.

Harloe, K. 2013: Winckelmann and the Invention of Antiquity: History and Aesthetics in the Age of Altertumswissenschaft. Oxford: Oxford University Press.

Harris, H. 2005: 'Indigenous Worldviews and Ways of Knowing as Theoretical and Methodological Foundations for Archaeological Research', in C. Smith \& H. Martin Wobst (eds), Indigenous Archaeologies: Decolonising Theory and Practice, 30-39. London, Routledge.

Hauser, J. 2015: German Religious Women in Late Ottoman Beirut: Competing Missions. Boston \& Leiden: Brill.

Hinsley, C. M. 1989: 'Revising and Revisioning the History of Archaeology: Reflections on Region and Context', in A. L Christenson (ed.), Tracing Archaeology's Past: The Historiography of Archaeology, 79-96. Carbondale: Southern Illinois University Press. 
Jones, W. E. 1913. 'A Brief Account and Description of an Important Collection of Archaeological Treasures \& Antiques Brought from Palestine by Baron von Ustinov, After 35 Years Research.' (Manuscript, Archives of the British Museum, Department of Greek and Roman Antiquities).

Kamel, L. 2015: Imperial Perceptions of Palestine: British Influence and Power in Late Ottoman Times. London: Tauris.

Kark, R. 1984: 'Changing Patterns of Landownership in Nineteenth-century Palestine: The European Influence' J Hist Geogr 10(4): 357-384.

Kark, R. 1990: Jaffa: A City in Evolution, 1799-1917. Jerusalem: Yad Izhak BenZvi Press.

Kark, R. 1994: American Consuls in the Holy Land, 1832-1914. Detroit: Wayne State University Press.

Kark, R. 2004: 'The Impact of Early Missionary Enterprises on Landscape and Identity Formation in Palestine, 1820-1914', ICMR 15(2): 209-235.

Kark, R. 2017: 'Consequences of the Ottoman Land Law: Agrarian and Privatization Processes in Palestine, 1858-1918', in R. Chand, E. Nel \& S. Pelc (eds), Societies, Social Inequalities and Marginalization, 101-119. Cham: Springer.

Kersel, M. 2010: 'The Changing Legal Landscape for Middle Eastern Archaeology in the Colonial Era, 1800-1930', in G. Emberling (ed.), Pioneers to the Past: American Archaeologists in the Middle East 1919-1920, 85-90. Chicago: The Oriental Institute Museum Publications.

Killebrew, A. E. 2005: Biblical Peoples and Ethnicity: An Archaeological Study of Egyptians, Canaanites, Philistines, and Early Israel, 1300-1100 B.C.E. Leiden: Brill.

Lucas, G. 2018: 'Fieldwork and Collecting', in D. Hicks \& M. C. Beaudry (eds), The Oxford Handbook of Material Culture Studies, 229-245. Oxford: Oxford University Press.

Layton, R. \& Wallace, G. 2008: 'Is Culture a Commodity?', in C. Scarre (ed.), The Ethics of Archaeology: Philosophical Perspectives on Archaeological Practice, 46-69. Cambridge: Cambridge University Press.

Mackenzie, S. 2011: 'The Market as Criminal and Criminals in the Market: Reducing Opportunities for Organised Crime in the International Antiquities 
Market', in S. Manacorda \& D. Chappell (eds), Crime in the Art and Antiquities World: Illegal Trafficking in Cultural Property, 69-85. New York: Springer.

Mackenzie, S. \& Green, P. 2009: 'Criminalising the Market in Illicit Antiquities', in S. Mackenzie \& P. Green (eds), Criminology and Archaeology: Studies in Looted Antiquities, 145-171. Oxford: Hart.

Maffi, I. 2010: 'The Intricate Life of Cultural Heritage: Colonial and Postcolonial Processes of Patrimonialisation in Jordan', in I. Maffi \& R. Daher (eds), The Politics and Practices of Cultural Heritage in the Middle East: Positioning the Material Past in Contemporary Societies, 66-104. London: Tauris.

Magness, J. 2012: The Archaeology of the Holy Land: From the Destruction of Solomon's Temple to the Muslim conquest. New York: Cambridge University Press.

Maner, B. 2018: Germany's Ancient Pasts: Archaeology and Historical Interpretation Since 1700. Chicago: The University of Chicago Press.

Meskell, L. 2009 (ed.) Cosmopolitan Archaeologies. Durham: Duke University Press.

Meskell, L. 2015: 'Heritage and Cosmopolitanism', in W. S. Logan, M. N. Craith \& U. Kockel (eds), A Companion to Heritage Studies, 479-490. Chichester: Wiley-Blackwell.

Meskell, L. \& Van Damme, L. S. M. 2007: 'Heritage Ethics and Descendant Communities', in C. Colwell \& T. J. Ferguson (eds), Collaboration in Archaeological Practice: Engaging Descendant Eommunities, 131-151. Lanham: AltaMira Press.

Noll, K. L. 2001: Canaan and Israel in Antiquity: An Introduction. London: Sheffield Academic Press.

O'Keefe, P. J. 1997: Trade in Antiquities: Reducing Destruction and Theft. London: Archetype Publications.

Opdyke, N. D, Lindsay, E. \& Kukla, G. 1983: 'Evidence for Earlier Date of Ubeidiya, Israel Hominid Site', Nature (304): 375.

Oz, A. 2000: The Silence of Heaven: Agnon's Fear of God. Princeton: Princeton University Press.

Paine, C. 2013: Religious Objects in Museums: Private Lives and Public Duties. London: Bloomsbury. 
Perî, Y. 2003: British Mission to the Jews in Nineteenth-Century Palestine. London: Frank Cass.

Perry, Y. \& Yodim, E. 2003: British Mission to the Jews in Nineteenth-Century Palestine. London: Taylor \& Francis.

Perry, Y. \& Lev, E. 2007: Modern Medicine in the Holy Land: Pioneering British Medical Services in Late Ottoman Palestine. London: Tauris.

Pipes, R. 1974: Russia Under the Old Regime. London: Weidenfeld \& Nicholson.

Pravilova, E. A. 2014: A public Empire: Property and the Quest for the Common Good in Imperial Russia. Princeton: Princeton University Press.

Rast, W. E. 1992: Through the Ages in Palestinian Archaeology: An Introductory Handbook. Philadelphia: Trinity Press International.

Renfrew, C. 2009: 'Collectors are the Real Looters', Archaeology 46(3): 16-17.

Renfrew, C. 2000: Loot, Legitimacy, and Ownership: The Ethical Crisis in Archaeology. London: Duckworth.

Sader, H. 2012: 'Between Looters and Private Collectors: The Tragic Fate of Lebanese Antiquities', in S. Mejcher-Atassi \& J. P Schwartz (eds), Archives, Museums and Collecting Practices in the Modern Arab World, 57-67. Farnham: Ashgate.

Schick. C. 1893: 'Palestine: Archaeological News', The American Journal of Archaeology and of the History of the Fine Arts 8(4): 557-631.

Shai, I. 2009: 'Understanding Philistine Migration: City Names and Their Implications', BASOR (354): 15-27.

Shanks, M. 1995: Classical Archaeology of Greece: Experiences of the Discipline. London: Routledge.

Shay, O. 2009: 'Collectors and Collections in Palestine at the Conclusion of the Ottoman Era', Le Muséon 122(3): 1-23.

Shaw, W. 2003: Possessors and Possessed: Museums, Archaeology, and the Visualization of History in the Late Ottoman Empire. Berkeley: University of California Press. 
Shaw, W. 2010: 'Heritage as Cultural Capital in the Late Ottoman Empire', in I. Maffi \& R. Daher (eds), The Politics and Practices of Cultural Heritage in the Middle East: Positioning the Material Past in Contemporary Societies, 55-66. London: Tauris.

Sicker, M. 1999: Reshaping Palestine: From Muhammad Ali to the British Mandate, 1831-1922. Westport: Praeger.

Skupinska-Lovset, I. 1976: The Ustinov Collection: the Palestinian Pottery. Oslo, Universitetsforlaget.

Smidt, W.G. 2005. 'Verbindungen der Familie Ustinov nach Äthiopien', Aethiopica 8(2005): 29-47.

Smith, C. \& Martin Wobst, H. 2005: 'Decolonizing Archaeological Theory and Practices', in C. Smith \& H. Martin Wobst (eds), Indigenous Archaeologies: Decolonising Theory and Practice, 4-15. London: Routledge.

Stähler, A. 2018: Zionism, the German Empire, and Africa: Jewish Metamorphoses and the Colors of Difference. Berlin: Walter De Gruyter.

Stanley-Price, N. (2001): 'The Ottoman Law on Antiquities (1874) and the Founding of the Cyprus Museum', in V. A. Tatton-Brown (ed.), Cyprus in the Nineteenth Century AD: Fact, Fancy and Fiction - Papers of the 22nd British Museum Classical Colloquium, December 1998, 267-275. Oxford: Oxbow Books.

Stiebing, W. H. 1993: Uncovering the Past: A History of Archaeology. New York: Oxford University Press.

Teissier, B. 1984: Ancient Near Eastern Cylinder Seals from the Marcopoli Collection. Berkeley: University of California Press.

Torlone, Z. M. 2014: Vergil in Russia: National Identity and Classical Reception. Oxford: Oxford University Press.

Trigger, B. 2008: 'More political Matter', in J. Cuno (ed.), Who Owns Antiquity? Museums and the Battle Over Our Ancient Heritage, 44-67. Princeton: Princeton University.

Tveit, O. K. 2000: Annas Bus. En Beretning fra Stavanger til Jerusalem. Oslo: Cappelen.

Ulph, J. 2011: 'Criminal Offences Affecting the Trade in Art and Antiquities', in J. Ulph, I. Smith \& M. Tugendhat (eds), The Illicit Trade in Art and Antiquities: 
International Recovery and Criminal and Civil Liability, 78-145. Oxford: Hart Publishing.

Ustinov, P. 1998: Dear Me. London: Arrow Books.

Vincent, L. H. 1904: 'Nouvelles trouvailles a Bersabée', RB 1(1): 84-89.

Vincent, L. H. 1908: 'Bustes funéraires Palestiniens', RB 5(1): 125-127.

Vogel, L. 1993: To See a Promised Land: Americans and the Holy Land in the Nineteenth Century. University Park: Pennsylvania State University Press.

Walsh, M. J. K. 2010: 'The Vile Embroidery of Ruin: Historic Famagusta Between Ottoman and British Empires in Fin de Siècle Cyprus: 1878-1901', J Intercult Stud 31(3): 247-269.

Walker Tubb, K. 2014: 'Extreme or Commonplace. The Collecting of Unprovenanced Antiquities', in W. Graeme \& J. C. H King (eds), Extreme Collecting: Challenging Practices for 21st Century Museums, 57-75. New York: Berghahn Books.

Watkins, J. 2005. 'Through Wary Eyes: Indigenous Perspectives on Archaeology', Annu. Rev. Anthropol (34): 429-449.

Waxman, D. 2019: The Israeli-Palestinian conflict. New York: Oxford University Press.

Weissbrod, L. 1992: Arab Relations with Jewish Immigrants and Israel, 1891-1991: The Hundred Year's Conflict. Lewiston: Mellen Press.

Wes, M. A. 1992: Classics in Russia, 1700-1855: Between Two Bronze Horsemen. Leiden: Brill.

Yates, D. 2015: 'Value and Doubt: The Persuasive Power of "Authenticity" in the Antiquities Market', Parse Journal (2): 1-84.

Yates, D. 2016: 'Museums, Collectors, and Value Manipulation: Tax Fraud Through Donation of Antiquities', J. Financ. Crime 23(1): 173-186.

Ziadeh, F. J. 1993: 'Property Rights in the Middle East: From Traditional Law to Modern Codes', Arab Law Q 8(1): 3-12. 